\title{
Creysse - Le Saraillet
}

n025989

\section{(2) OpenEdition \\ Journals}

Édition électronique

URL : http://journals.openedition.org/adlfi/16366

ISSN : 2114-0502

Éditeur

Ministère de la culture

\section{Référence électronique}

"Creysse - Le Saraillet », ADLFI. Archéologie de la France - Informations [En ligne], Aquitaine, mis en ligne le 10 février 2016, consulté le 02 mai 2019. URL : http://journals.openedition.org/adlfi/16366

Ce document a été généré automatiquement le 2 mai 2019

(C) Ministère de la Culture et de la Communication, CNRS 


\section{Creysse - Le Saraillet}

n025989

Notice non parvenue.

INDEX

operation Fouille préventive (FP) 